\title{
Pelaksanaan Jaminan Hak Keperdataan Subyek Hukum Manusia Atas Perubahan Atau Penambahan Nama Dalam Hukum Positif Indonesia Di Serang Banten
}

\author{
Dede Agus*, Lia Riesta Dewi \\ Fakultas Hukum Universitas Sultan Ageng Tirtayasa, Serang-Banten \\ *Correspondence email: de298gus@gmail.com
}

\begin{abstract}
Abstrak, Sesuai dengan hak atas penamaan itu hak dari setiap subyek hukum manusia, perubahan atau penambahan nama juga demikian. Oleh karena itu, penelitian ini hendak mengkaji bagaimana jaminan dan pelaksanaan hak keperdataan atas perubahan atau penambahan nama dalam hukum positif dan akibat hukumnya terhadap dokumen kependudukan dan dokumen hukum lainya. Metode penelitian ini tipe penelitian hukum, yaitu penelitian untuk mencari pemecahan atas isu hukum, yang jenisnnya yuridis normative, pendekatan perundang-undangan dan konseptual, data sekunder dan primer sebagai penunjang, serta akhirnya dianalisa deskriptif kualitatif. Hasil penelitian bahwa perubahan atau penambahan nama dalam dokumen kependudukan dan catatan sipil telah dijamin secara implisit dan secara eksplisit oleh UU No. 23 Th 2006 Tentang Administrasi Kependudukan dan UU No. 24 Th 2013 tentang perubahannya, serta peraturan pelaksanaannya. Begitu pula pelaksanaan hak keperdataan atas perubahan atau penambahan nama dalam dokumen kependudukan dan catatan sipil, serta dokumen lainya dalam praktek telah berjalan. Akibat hukum yang timbul: harus memperoleh penetapan pengadilan negeri, permohonan perubahan ke Disdukcapil, catatan pinggir pada register Akta, merubah identitas nama pada dokumen kependudukan lainnya, serta dikenakan sanksi administrasi kependudukan sesuai UU Adminduk.
\end{abstract}

Kata kunci: Subyek Hukum; Hak Keperdataan; Perubahan/Penambahan Nama; Hukum Positif

\begin{abstract}
In accordance with the right to naming the rights of each subject human law, the change or addition of names are also the same. Therefore, this research aims to describe how the guarantee and implementation of civil rights for the change or addition of names in positive law and the legal consequences for population documents and other legal documents. This research method, normative juridical based on secondary data and much supported primary data, and finally were analysed qualitative descriptive. The research result shows that the change or addition of names in population documents and civil registries has been guaranteed implicitly and explicitly by the Law No. 23 of 2006 on Population Administration and Law No.24 of 2013 on the amendments law, and it implementation regulations. Likewise, the implementation of civil rights for changes or additions to names in population documents and civil registries, as well as other documents has been in practice. Due to law arising, such as: must obtain a district court decisions, a request for a changes to the population and civil registries, margin notes on the deed register, change the name of other population identity on a documents, as well as sanctions had been imposed on population administration in according to the population administration Law.
\end{abstract}

Keywords: Subject of Law; Civil Rights; Name Change/Addition; Positive Law.

\section{PENDAHULUAN}

Manusia sebagai subyek hukum tentu dapat mempunyai hak dan kewajiban menurut hukum yang menurut Sudikno Mertokusumo (2013) subyek hukum adalah segala sesuatu yang dapat memperoleh, mempunyai atau menyandang hak dan kewajiban (Sudikno Mertokusumo, 2003). Kata lain subyek hukum segala sesuatu yang dianggap dapat mempunyai kewenangan hukum atau kewenangan berhak. Kata mempunyai hak dan kewajiban bersifat pasif/belum aktif, juga dianggap dapat mempunyai hak dan kewajiban merupakan anggapan hukum, sedangkan kewenangan hukum adalah kewenangan untuk mempunyai hak dan kewajiban juga bersifat pasif. Kewenangan berbuat berarti kedudukan manusia dalam keadaan aktif.

Diantara sekian banyak hak yang harus dimiliki atau dituntut oleh manusia adalah hak atas penamaan. Manusia sebagai subyek hukum (naturlijke persoon) lazimnya memiliki nama yang disandangnya. Menyandang nama disamping merupakan hak sebagai subyek hukum, juga menandakan eksistensinya manusia dalam pergaulan hidup sosial dan masyarakat. Menyandang nama maka seseorang manusia akan mudah diidentifikasi dalam pergaulan hidup sosial dan masyarakat, karena nama memiliki fungsi untuk mengidentifikasi manusia sebagai subyek hukum. Menurut kamus nama adalah kata untuk menyebut atau memanggil orang, tempat, barang, binatang dan sebagainya, gelar, sebutan, kemasyhuran, kebaikan, keunggulan, kehormatan (Mahfan, 2005). Nama merupakan identifikasi seseorang sebagai subyek hukum, dari nama itu sudah diketahui keturunan siapa orang yang bersangkutan. Nama sangat penting dalam urusan pewarisan serta soal-soal lain yang berhubungan dengan kekeluargaan.

Banyak faktor yang menjadi bahan pertimbangan dalam penamaan manusia sebagai subyek hukum, mulai 
Dede Agus dan Lia Riesta Dewi, Pelaksanaan Jaminan Hak Keperdataan Subyek Hukum Manusia Atas Perubahan Atau Penambahan Nama Dalam Hukum Positif Indonesia Di Serang Banten

dari faktor agama, adat, kebiasaan, sosial kemasyarakatan, faktor hukum dan faktor jenis kelamin. Dalam hal faktor jenis kelamin, lazimnya masyarakat memberikan nama yang berbeda kepada laki-laki dan perempuan, jadi memberikan nama yang biasa disandang laki-laki kepada subyek hukum laki-laki dan memberikan nama yang biasa disandang perempuan kepada perempuan. Menurut Akhmad Zulkarnain (2016), dalam memberikan nama kepada anaknya, manusia memikirkan nama yang diberikan merupakan nama maskulin untuk laki-laki dan nama feminim untuk perempuan. Namun dapat juga dipertukarkan, yaitu nama yang biasa disandang laki-laki diberikan kepada perempuan dan sebaliknya, serta adanya nama uniseks, yaitu nama yang dapat digunakan baik untuk laki-laki maupun perempuan. Lebih jelasnya Akhmad Zulkarnain (2016), menyatakan:

Uniseks adalah hal yang tidak dikaitkan dengan jenis kelamin tertentu atau keadaan yang tidak dikaitkan dengan jenis kelamin tertentu. Dihubungkan dengan nama, nama uniseks berarti nama yang tidak berkaitan dengan jenis kelamin tertentu. Oleh karena tidak berkaitan dengan jenis kelamin tertentu, nama kategori ini dapat digunakan baik untuk laki-laki maupun perempuan. Adanya nama uniseks disebabkan bergesernya ciri-ciri nama maskulin dan feminim.

Meskipun subyek hukum manusia telah mempertimbangkan banyak faktor dalam penamaan, namun kadangkala terjadi perubahan atau penambahan nama yang disandangnya. Dalam perubahan atau penambahan nama ini kelihatannya sederhana, namun jika berkaitan dengan dokumen penting dan dokumen kependudukan lainya (seperti : ijazah, sertifikat, sim, paspor, akta kelahiran, akta kematian, akta nikah, akta perceraian, kartu keluarga (KK) dan KTP) sebagai legalitas warga negara tentu tidak sederhana, karena harus menempuh prosedur perubahan atau penambahan nama sesuai dengan peraturan perundangan yang berlaku. Meskipun demikian sebagaimana hak atas penamaan itu hak dari setiap subyek hukum manusia maka perubahan atau penambahan nama juga sama merupakan hak dari setiap subyek hukum manusia.

Jaminan atas perubahan atau penambahan nama subyek hukum manusia pada awalnya diatur dalam Buku I Titel II bagian kedua (pasal 5a s/d 12 KUH Perd) yang menentukan tentang nama, perubahan nama-nama dan perubahan nama-nama depan. Namun dengan berlakunya UU No.4 Tahun 1961 tentang Perubahan atau Penambahan Nama Keluarga maka pasal-pasal KUH Perd yang mengatur nama tidak berlaku lagi. Kini pengaturannya dalam UU No. 23 Tahun 2006 Tentang Administrasi Kependudukan dan UU No.24 Tahun 2013 Tentang Perubahan Atas UU No. 23 Tahun 2006. UU
Administrasi Kependudukan ini juga mencabut berlakunya Buku I Titel II bagian kedua KUH Perd dan UU No. No.4 Tahun 1961 dalam pasal 106 huruf a dan f. Paragraf 1 tentang Pencatatan Perubahan Nama dan Pasal 52 Undang-Undang No. 23 Tahun 2006 Tentang Administrasi Kependudukan berbunyi:

(1). Pencatatan perubahan nama dilaksanakan berdasarkan penetapan pengadilan negeri tempat pemohon.

(2). Pencatatan perubahan nama sebagaimana dimaksud pada ayat (1) wajib dilaporkan oleh Penduduk kepada Instansi Pelaksana yang menerbitkan akta Pencatatan Sipil paling lambat 30 (tiga puluh) hari sejak diterimanya salinan penetapan pengadilan negeri oleh Penduduk.

(3). Berdasarkan laporan sebagaimana dimaksud pada ayat (2), Pejabat Pencatatan Sipil membuat catatan pinggir pada register akta Pencatatan Sipil dan kutipan akta Pencatatan Sipil.

Dengan demikian perubahan atau penambahan nama orang dilakukan setelah mendapatkan pengajuan dari yang berkepentingan dan penetapan dari pengadilan negeri. Subyek hukum manusia tentu saja mengajukan permohonan perubahan atau penambahan nama disertai dengan alasan-alasan yang kuat agar mendapat penetapan dari pengadilan negeri dan atas dasar penetapan pengadilan negeri Pejabat Pencatatan Sipil membuat catatan pinggir pada register akta Pencatatan Sipil dan kutipan akta Pencatatan Sipil. Akta catatan sipil, yaitu catatan autentik hasil pencatatan tentang peristiwa penting seperti kelahiran, perkawinan dan perceraian, pengakuan anak, pengesahan anak, pengangkatan anak, kematian, perubahan nama dan perubahan status kewarganegaraan. Dalam hal ini Pejabat Pencatatan Sipil membuat catatan pinggir pada register akta Pencatatan Sipil dan kutipan akta Pencatatan Sipil seperti kelahiran, perkawinan dan perceraian, pengakuan anak, pengesahan anak, dan pengangkatan anak. Perubahan atau penambahan nama ini disamping berdampak pada perubahan akta-akta catatan sipil yang telah diterbitkan juga akan berdampak pada dokumen penting dan dokumen kependudukan lainya seperti : ijazah, sertifikat, sim, paspor, kartu keluarga (KK) dan KTP) serta perbuatan hukum lainnya yang berbasis dokumen. Pencatatan sipil menurut pasal 1 angka 15 UU No. 24 Tahun 2013 adalah pencatatan peristiwa penting yang dialami oleh seseorang dalam register Pencatatan Sipil pada Instansi Pelaksana. Yang dimaksud peristiwa penting menurut pasal 1 angka 17 adalah : "kejadian yang dialami oleh seseorang meliputi kelahiran, kematian, lahir mati, perkawinan, perceraian, pengakuan anak, pengesahan anak, pengangkatan anak, perubahan nama dan perubahan status kewarganegaraan", Oleh karena itu, perlu penelitian terhadap pelaksanaan jaminan hak keperdataan subyek hukum manusia atas 
Dede Agus dan Lia Riesta Dewi, Pelaksanaan Jaminan Hak Keperdataan Subyek Hukum Manusia Atas Perubahan Atau Penambahan Nama Dalam Hukum Positif Indonesia Di Serang Banten

perubahan atau penambahan nama dalam hukum positif Indonesia di Serang-Banten dalam rangka mengkaji secara konkrit penerapan hukum oleh lembaga penegak hukum dan lembaga administrasi kependudukan dan catatan sipil. Berdasarkan hal tersebut, maka rumusan masalah dalam penelitian ini adalah: (a) Bagaimana jaminan dan pelaksanaan hak keperdataan atas perubahan atau penambahan nama dalam hukum positif Indonesia di Serang Banten? dan (b) Bagaimana akibat hukum adanya perubahan atau penambahan nama manusia sebagai subyek terhadap dokumen kependudukan dan dokumen hukum lainya?

\section{METODE}

Penelitian ini adalah penelitian hukum yang jenisnya yuridis normatif, dilakukan untuk mencari pemecahan atas isu hukum dan hasil yang dicapai memberikan preskripsi mengenai apa yang seyogyanya atas isu yang diajukan (Peter Mahmud Marzuki, 2007). Pendekatan yang digunakan pendekatan perundangundangan (statute approach) dilakukan dengan meneliti dan menelaah perundang-undangan yang memuat ketentuan-ketentuan tentang pencatatan sipil dan kependudukan, pendekatan konseptual (conceptual approach) dilakukan untuk memahami konsep-konsep hukum keperdataan, dan pendekatan kasus (case approach) dilakukan dengan meneliti dan menelaah penetapan pengadilan tentang penambahan dan perubahan nama. Data dan Sumber data adalah data sekunder (penelitian kepustakaan) dan data primer (penelitian lapangan) sebagai pendukung/penunjang. Akhirnya data primer dan sekunder diolah serta dilakukan analisa secara deskriptif kualitatif.

\section{HASIL DAN PEMBAHASAN}

Jaminan dan Pelaksanaan Hak Keperdataan Atas Perubahan Atau Penambahan Nama Dalam Hukum Positif

\section{Jaminan Penamaan Manusia Dalam Hukum Positif Indonesia}

Hukum positif yang dimaksud di sini adalah Kitab Undang-Undang Hukurn Perdata (KUH Perd), UU No. 39 Th 1999 tentang Hak Asasi Manusia, UU No. 23 Th 2002 tentang Perlindungan Anak, UU No.1 Th 1974 Tentang Perkawinan, UU No. 23 Th 2006 Tentang Administrasi Kependudukan dan UU No.24 Th 2013 Tentang Perubahan Atas UU No. 23 Th 2006 Tentang Administrasi Kependudukan. Dalam peraturan perundangan-undangan tersebut secara implisit dan eksplisit mengatur jaminan penamaan subyek hukum manusia.

Penamaan manusia sebagai subyek hukum dalam hukum perdata diatur dalam Buku I Titel II bagian kedua (pasal 5a s/d 12 KUH Perd) yang menentukan tentang nama, perubahan nama-nama dan perubahan nama-nama depan. Kemudian dengan berlakunya UU No.23 Th
2006 Tentang Administrasi Kependudukan ketentuan tersebut menjadi tidak berlaku. Pasal 106 huruf (a) UU No. 23 Th 2006 Tentang Administrasi Kependudukan, menyakan bahwa: "Buku Kesatu Bab Kedua Bagian Kedua dan Bab Ketiga Kitab Undang-Undang Hukum Perdata (Burgerlijk Wetboek voor Indonesie, Staatsblad 1847:23); dicabut dan dinyatakan tidak berlaku. Penamaan manusia sebagai subyek hukum dalam hal pencatatan sipilnya kini diatur oleh UU No. 23 Th 2006 Tentang Administrasi Kependudukan dan UU No.24 Th 2013 Tentang Perubahan UU No.23 Tahun 2006 beserta peraturan pelaksanaannya.

UU No.39 Th 1999 tentang Hak Asasi Manusia (UU HAM) menjamin hak anak atas pemberian nama, dimana hak atas nama merupakan salah satu hak asasi manusia sebagai subyek hukum yang telah dijamin oleh undang-undang tersebut. Hal ini ditegaskan dalam pasal 52 ayat (2) UU HAM, yang berbunyi :'Hak anak adalah hak asasi manusia dan untuk kepentingannya hak anak itu diakui dan dilindungi oleh hukum bahkan sejak dalam kandungan". Hak anak atas pemberian nama tersebut terdapat dalam Pasal 53 ayat (2) menyatakan bahwa :"Setiap anak sejak kelahirannya, berhak atas suatu nama dan status kewarganegaraan". Yang dimaksud nama menurut penjelasan pasal 53 ayat (2) tersebut adalah nama sendiri, dan nama orang tua kandung, dan atau nama keluarga, dan atau nama marga.

UU No.23 Th 2002 Tentang Perlindungan Anak ini sebagai bentuk jaminan perlindungan kepada anak, dimana salah satu bentuk perlindungan tersebut berupa pemberian nama kepada anak sebagai identitas diri. Pasal 5 UU Perlindungan Anak menyatakan bahwa: "Setiap anak berhak atas suatu nama sebagai identitas diri dan status kewarganegaraan". Hak anak atas nama ini pun menurut Penjelasan Umum Pasal 1 angka 12 UU No.35 Th 2014 Tentang Perubahan Atas UU No.23 Th 2002 tentang Perlindungan Anak adalah bagian dari hak asasi manusia yang wajib dijamin, dilindungi, dan dipenuhi oleh Orang Tua, Keluarga, masyarakat, negara, pemerintah, dan pemerintah daerah. Hak anak atas suatu nama sebagai identitas diri kemudian dituangkan dalam bentuk akta kelahiran. Akta kelahiran memiliki peran penting bagi anak sebagai pengakuan bagi dirinya, dan juga menghindari tindakan yang merugikan bagi anakanak, seperti eksploitasi, dan pemalsuan identitas serta untuk keperluan-keperluan lainnya (Muslim Zainuddin dan Mansari, 2018). Pasal 27 ayat (1) dan (2) UU No. 35 Th 2014, berbunyi : “(1) Identitas diri setiap Anak harus diberikan sejak kelahirannya; dan (2) Identitas sebagaimana dimaksud pada ayat (1) dituangkan dalam akta kelahiran". Kemudian Pasal 28 UU No. 35 Th 2014 tentang Perubahan Atas UU No.23 Th 2002, mengatur tentang pembuatan akta kelahiran, yaitu:

(1). Pembuatan akta kelahiran dilakukan oleh instansi yang menyelenggarakan urusan pemerintahan di bidang administrasi kependudukan. 
Dede Agus dan Lia Riesta Dewi, Pelaksanaan Jaminan Hak Keperdataan Subyek Hukum Manusia Atas Perubahan Atau Penambahan Nama Dalam Hukum Positif Indonesia Di Serang Banten

(2). Pencatatan kelahiran diselenggarakan paling rendah pada tingkat kelurahan/desa.

(3). Akta kelahiran sebagaimana dimaksud pada ayat (1) diterbitkan paling lambat 30 (tiga puluh) hari sejak tanggal dipenuhinya semua persyaratan sesuai dengan ketentuan peraturan perundang-undangan.

(4). Pembuatan akta kelahiran sebagaimana dimaksud pada ayat (1) tidak dikenai biaya.

(5). Ketentuan mengenai tata cara dan syarat pembuatan akta kelahiran sebagaimana dimaksud pada ayat (1) dilaksanakan sesuai dengan ketentuan peraturan perundang-undangan."

UU No.1 Th 1974 tentang Perkawinan mengatur mengenai perkawinan, yang juga mengakui eksistensi akta kelahiran dalam hal pembuktian asal usul anak. Pasal 55 ayat (1) UU No.1 Th 1974 berbunyi: "asal usul seorang anak hanya dapat dibuktikan dengan akta kelahiran yang otentik, yang dikeluarkan oleh pejabat yang berwenang". Dari ketentuan pasal tersebut dapat simpulkan bahwa peranan dan manfaat akta kelahiran adalah guna memberikan kepastian hukum bagi seorang anak yang telah lahir ke dunia, yang dilindungi hakhaknya sebagai subyek hukum. Akta kelahiran diperoleh setelah dilakukan pencatatan kelahiran (pencatatan sipil) oleh Kantor Disdukcapil.

UU No.23 Th 2006 Tentang Administrasi Kependudukan dan UU No.24 Th 2013 Tentang Perubahan Atas UU No.23 Th 2006 ini mengatur mengenai pencatatan peristiwa hukum, diantaranya peristiwa kelahiran, dimana pencatatan tersebut meliputi pencatatan hari, tanggal, bulan, tahun, tempat kelahiran, nama subyek hukumnya dan orang tua dari subyek hukum tersebut. Pencatatan peristiwa hukum kelahiran ini diselenggarakan oleh lembaga pencatatan sipil. Dari pencatatan peristiwa hukum kelahiran ini akan diterbitkan dalam suatu akta autentik berupa kutipan akta kelahiran. Akta kelahiran yaitu akta yang dikeluarkan oleh pejabat yang berwenang yang berkaitan dengan adanya kelahiran. Sedangkan akta autentik adalah akta yang dibuat dan dihadapan pejabat yang diberi wewenang untuk itu, menurut ketentuan yang telah ditetapkan, baik dengan maupun tanpa bantuan dari yang berkepentingan, yang mencatat apa yang dimintakan untuk dibuat keterangan seorang pejabat, yang menerangkan apa yang dilakukannya dan dilihat dihadapannya. Dengan demikian akta kelahiran termasuk alat bukti tertulis berbentuk akta autentik. Akta autentik pada umumnya mempunyai kekuatan pembuktian lahir, kekuatan pembuktian formal dan kekuatan pembuktian materil. Kekuatan pembuktian akta catatan sipil memiliki kekhususan/keistimewaan yang berbeda dengan akta lainnya, jika pada akta biasa kekuatan pembuktian terletak pada akta aslinya (pasal 1888 KUH Perd), maka pada akta catatan sipil baik itu kutipan akta maupun salinan akta adalah sama, yakni mempunyai kekuatan pembuktian yang sempurna seperti akta aslinya.

Catatan sipil artinya catatan mengenai peristiwa perdata yang dialami oleh seseorang. Tujuan pencatatan sipil ini adalah untuk memperoleh kepastian hukum tentang status perdata seseorang yang mengalami peristiwa hukum, yang dalam kehidupan manusia ada lima peristiwa hukum seperti : kelahiran, perkawinan, perceraian, kematian dan penggantian nama. Lebih luasnya catatan sipil atau pencatatan sipil merupakan suatu lembaga yang sengaja dibentuk oleh pemerintah dengan tugas menyelenggarakan pencatatan, penerbitan, penyimpanan, dan pemeliharaan data keperdataan seseorang, seperti : kelahiran, perkawinan, perceraian, kematian, pengakuan dan pengesahan anak, seperti penggantian nama atau pencatatan sipil bertugas membantu pemerintah dalam menyelenggarakan pencatatan peristiwa hukum seseorang agar status hukumnya pasti, jelas dan terang (Rahmadi Usman, 2006). Menurut Pasal 1 angka 17 Penjelasan Umum UU No. 24 Th 2013 disebut dengan peristiwa penting, yaitu kejadian yang dialami oleh seseorang meliputi kelahiran, kematian, lahir mati, perkawinan, perceraian, pengakuan anak, pengesahan anak, pengangkatan anak, perubahan nama dan perubahan status kewarganegaraan. Hasil pencatatan sipil tersebut akan diterbitkan akta catatan sipil, yaitu catatan autentik hasil pencatatan tentang peristiwa penting.

UU Administrasi Kependudukan ini hanya melegitimasi nama yang sudah disandang oleh manusia (orang) sebagai subyek hukum ke dalam sebuah akta autentik yang dikenal dengan nama akta kelahiran, sedangkan masalah pemberian nama masih diserahkan kepada subyek hukum manusia itu sendiri sesuai tradisi dan kebiasaan masyarakat setempat. Namun pemberian nama di sini tidak bisa dipisahkan dengan perbuatan hukum selanjutnya dalam rangka pengakuan hukum atas identitas nama yang dituangkan dalam bentuk akta kelahiran, yang telah diatur dalam hukum positif (UU No.23 Th 2006 Tentang Adminduk dan UU No.24 Th 2013 Tentang Perubahannya).

\section{Perubahan Atau Penambahan Nama Subyek Hukum Manusia}

Kata-kata dari pujangga William Shakespeare yang berbunyi: "apalah arti sebuah nama"? Dari pernyataan tersebut bisa disimpulkan bahwa bagi Shakespeare, nama bukanlah hal yang penting, namun tidak berlaku bagi sebagian orang, buktinya banyak di antara mereka yang memilih mengganti nama dengan berbagai alasan (Fadila Adelin, 2015). Seperti dikemukakan oleh Teten Tendiyanto (2014) bahwa nama yang disandang mengandung makna sebagaimana di bawah ini (Teten Tendiyanto, 2014) :

(1). Arti nama menurut masyarakat/kebiasaan : nama adalah suatu identitas yang harus dimiliki oleh 
seseorang pada saat dilahirkan untuk mempermudah pemanggilan.

(2). Arti nama menurut Agama : nama adalah do'a, kata panggilan yang diberikan oleh orang tua kepada anaknya sebagai harapan, implikasi dari nama sebagai do'a sudah tersirat dalam sebuah nama.

(3). Istilah nama : nama merupakan hal penting, karena nama dijadikan bukti diri seseorang sebagai subyek hukum. Dari nama dapat diketahui keturunan siapa, penting dalam urusan pembagian warisan serta masalah kekeluargaan.

(4). Subyek hukum mempunyai nama : dikenal dua subyek hukum, yaitu manusia (orang) dan badan hukum. Diantara kedua subyek hukum diperlukan sebuah identitas untuk mempermudah dalam menerapkan dan mengontrol subyek hukum.

(5). Urgensi nama : nama merupakan hal yang sangat penting dikarenakan nama sebagai identitas diri dalam kehidupan sehari-hari, berkomunikasi dan bersosialisasi dalam masyarakat, dan bagi segala kepentingan administrasi kependudukan.

Berhubung nama mengandung makna seperti yang disebutkan di atas, maka dalam pembentukan atau pemberian nama pun sangat berhati-hati, penuh pertimbangan bahkan perencanaan yang matang sesuai dengan adat dan tradisi masyakat, asal pulau, suku, kebudayaan, bahasa, pendidikan yang diterima orang tua dan agama yang dianutnya. Namun nama yang disandang oleh subyek hukum manusia tidak selamanya dapat dipertahankan sesuai pemberian/pembentukan nama pertama kali, dalam hal ini dapat mengalami perubahan atau penambahan nama dengan berbagai alasan dari diri sendiri atau karena keluarga. Menurut Nirmayanti Wening Prasasti (pegawai pengadilan negeri), berbagai alasan orang mengganti nama mereka adalah: (Fadila Adelin, 2015):_(a) Merasa malu : karena nama yang tidak sesuai jenis kelaminnya; (b) Namanya identik dengan agama yang tidak dianutnya: ketika seseorang pindah agama dan mengganti dengan nama yang identik dengan agama yang dianutnya. (c) Permasalahan keluarga: mengganti nama karena latar belakang keluarganya yang buruk; (d) Namanya ternyata memiliki arti yang buruk: memberi nama anak memang harus hati-hati, jangan asal digunakan; (e) Namanya berbau politis: memiliki muatan politis ganti nama; (f) Ingin menambahkan nama belakang suami: biasanya terjadi pada wanita yang memiliki mertua atau suami terpandang, untuk mengangkat derajat si istri; dan (g) Sering sakit-sakitan: adalah alasan yang paling sering digunakan untuk ganti nama.

Perihal perubahan atau penambahan nama merupakan peristiwa biasa saja meskipun bagi masyarakat tertentu harus dilakukan sesuai adat tradisi masyarakat tersebut, jika belum dituangkan dalam dokumen kependudukan/pencatatan sipil. Namun jika perubahan atau penambahan nama dilakukan setelah dituangkan dalam dokumen kependudukan/pencatatan sipil maka dapat menjadi peristiwa hukum. Peristiwa hukum adalah peristiwa yang relevan bagi hukum, peristiwa yang oleh hukum dihubungkan dengan akibat hukum atau dihubungkan dengan timbul atau lenyapnya hak dan kewajiban, peristiwa yang oleh hukum diberi akibat hukum (Sudikno Mertokusumo, 2003). Oleh karena itu jika perubahan atau penambahan nama dilakukan setelah dituangkan dalam dokumen kependudukan/pencatatan sipil maka nama hasil perubahan atau penambahan nama tidak dapat diakui secara hukum, dalam arti nama yang tercantum dalam dokumen kependudukan/pencatatan sipil itulah yang diakui secara hukum. Jika ingin diakui secara hukum harus melakukan pula perubahan atau penambahan nama dalam dokumen kependudukan/pencatatan sipil.

Perubahan atau penambahan nama subyek hukum manusia yang telah tercantum dalam dokumen kependudukan/pencatatan sipil diperbolehkan dan telah mendapatkan jaminan hukum, sebagaimana disebutkan dalam pasal 52 tentang Pencatatan Perubahan Nama UU No. 23 Tahun 2006 Tentang Administrasi Kependudukan, yang berbunyi :

(1). Pencatatan perubahan nama dilaksanakan berdasarkan penetapan pengadilan negeri tempat pemohon.

(2). Pencatatan perubahan nama sebagaimana dimaksud pada ayat (1) wajib dilaporkan oleh Penduduk kepada Instansi Pelaksana yang rnenerbitkan akta Pencatatan Sipil paling lambat 30 (tiga puluh) hari sejak diterimanya salinan penetapan pengadilan negeri oleh Penduduk.

(3). Berdasarkan laporan sebagaimana dimaksud pada ayat (2), Pejabat Pencatatan Sipil membuat catatan pinggir pada register akta Pencatatan Sipil dan kutipan akta Pencatatan Sipil.

Kemudian berdasarkan Perpres No.96 Th 2018 Tentang Persyaratan dan Tata Cara Pendaftaran Penduduk dan Pencatatan Sipil, Pasal 53 tentang Pencatatan Perubahan Nama, yaitu bahwa pencatatan perubahan nama penduduk harus memenuhi persyaratan: (a) salinan penetapan pengadilan negeri; (b) kutipan akta Pencatatan Sipil; (c) KK; (d) KTP-e1; dan (e) Dokumen Perjalanan bagi Orang Asing. Dengan demikian perubahan atau penambahan nama subyek hukum manusia dilakukan setelah mendapatkan penetapan dari pengadilan negeri dan mengajukan permohonan perubahan atau penambahan nama ke Disdukcapil. Berikut prosedur/tata cara perubahannya:

\section{a. Penetapan Pengadilan Negeri}

Penetapan Pengadilan Negeri merupakan perbuatan hukum dari hakim yang mengabulkan permohonan pemohon melalui sidang permohonan 
perubahan atau penambahan nama. Penetapan adalah keputusan pengadilan atau pernyataan hakim yang dituangkan dalam bentuk tertulis dan diucapkan oleh hakim dalam sidang terbuka untuk umum sebagai hasil pemeriksaan perkara permohonan (voluntair), misalnya penetapan dalam perkara dispensasi nikah, izin nikah, wali adhal, poligami, perwalian, itsbat nikah, perubahan atau penambaha nama dan sebagainya. Penetapan merupakan jurisdiction valuntaria yang berarti bukan peradilan yang sesungguhnya karena pada penetapan hanya ada permohon tidak ada lawan hukum. Di dalam penetapan, Hakim tidak menggunakan kata "mengadili", namun cukup dengan menggunakan kata "menetapkan"

(http://dariuslekalawo.blogspot.com/search/label/ilmu , 2015).

Penetapan pengadilan negeri menjadi syarat awal/pertama dalam perubahan atau penambahan nama subyek hukum manusia dalam dokumen pencatatan sipil berupa akta kelahiran. Hal ini berdasarkan ketentuan pasal 52 ayat (1) UU No. 23 Th 2006 Tentang Administrasi Kependudukan, yang menyatakan bahwa: "Pencatatan perubahan nama dilaksanakan berdasarkan penetapan pengadilan negeri tempat pemohon". Menurut pasal 53 huruf (a) Perpres No. 96 Tahun 2018 Tentang Persyaratan dan Tata Cara Pendaftaran Penduduk dan Pencatatan Sipil, berdasarkan salinan penetapan pengadilan negeri.

Untuk memperoleh penetapan pengadilan harus mengajukan permohonan perubahan atau penambahan nama disertai dengan alasan-alasannya. Alasan-alasan tersebut dalam hukum acara perdata disebut dengan landasan permohonan (posita) dan juga memuat permintaan (petitum), dalam hal ini permintaan perubahan atau ganti nama. (M Yahya Harahap, 2016). Menurut hukum online UU No. 23 Th 2006 Tentang Administrasi Kependudukan jo UU No.24 Th 2013 tentang Perubahannya tidak mengatur secara eksplisit bahwa permohonan perubahan atau penambahan nama di pengadilan negeri harus mencantumkan alasa-alasannya. Namun karena tidak mengatur maka berlakulah hukum acara perdata, yaitu harus memuat posita dan petitum. (Dimas Hutomo, 2019). Berikut contoh permohonan perubahan atau penambahan nama dan penetapan dari pengadilan negeri.

Tabel 1. Penetapan Permohonan Perubahan Atau Penambahan Nama di PN Serang

\begin{tabular}{|c|c|c|c|c|c|c|}
\hline \multirow[t]{2}{*}{ No } & \multirow{2}{*}{ No Perkara } & \multirow{2}{*}{$\begin{array}{c}\text { Tgl } \\
\text { Register }\end{array}$} & \multirow{2}{*}{ Perkara } & \multirow{2}{*}{ Pemohon } & \multicolumn{2}{|c|}{ Keadaan/Fakta Hukum } \\
\hline & & & & & Awal & Penetapan \\
\hline \multirow[t]{2}{*}{1} & 116/Pdt.P/2020/PN Srg & $02 / 7 / 2020$ & Permohonan & Safrianto (Ortu) & Bilqis & Salsabila Bilqis \\
\hline & & & Ganti Nama & & $\begin{array}{l}\text { Oktaviani } \\
\text { Putri }\end{array}$ & Oktaviani Putri \\
\hline \multirow[t]{2}{*}{2} & 94/Pdt.P/2020/PN.Srg & $05 / 5 / 2020$ & Permohonan & Nurzen (Ortu) & Muhammad & Gibran Nur Afrian \\
\hline & & & Ganti Nama & & $\begin{array}{l}\text { Akbar Nur } \\
\text { Afriansyah }\end{array}$ & Akbar \\
\hline \multirow[t]{2}{*}{3} & 93/Pdt.P/2020/PN.Srg & $29 / 4 / 2020$ & Permohonan & Anisa & Anisa & Michelle Anneliese \\
\hline & & & Ganti Nama & Handayani & Handayani & Devara Handayani \\
\hline \multirow[t]{2}{*}{4} & 87/Pdt.P/2020/PN.Srg & $09 / 4 / 2020$ & Permohonan & Tubagus & Elmira & Assyifa Agiesyabilla \\
\hline & & & Ganti Nama & $\begin{array}{l}\text { Hardiyanto } \\
\text { (Ortu) }\end{array}$ & $\begin{array}{l}\text { Shanum } \\
\text { Agiesyabilla }\end{array}$ & \\
\hline \multirow[t]{2}{*}{5} & 83/Pdt.P/2020/PN.Srg & $31 / 3 / 2020$ & Permohonan & Maman & Maman & Maman Nuralam \\
\hline & & & Ganti Nama & Nuralam & & \\
\hline 6 & 119/Pdt.P/2020/PN.Srg & $14 / 7 / 2020$ & $\begin{array}{l}\text { Perbaikan } \\
\text { kesalahan dlm } \\
\text { akta kelahiran }\end{array}$ & M Idris & $\begin{array}{l}\text { Muhamad } \\
\text { Idris }\end{array}$ & M. Idris \\
\hline 7 & 115/Pdt.P/2020/PN.Srg & $02 / 7 / 2020$ & $\begin{array}{l}\text { Perbaikan } \\
\text { kesalahan dlm } \\
\text { akta kelahiran }\end{array}$ & Muhaemin & Muhemin & Muhaemin \\
\hline
\end{tabular}

Sumber : Sistem Informasi Penelusuran Perkara (SIPP) PN Serang, 2020.

b. Permohonan Pencatatan Perubahan atau Penambahan Nama di Dinas Kependudukan dan Catatan Sipil

Pencatatan peristiwa penting kependudukan dilakukan di Dinas Kependudukan dan Catatan Sipil, dan perubahan atau penambahan nama juga termasuk di dalamnya. Menurut pasal 1 angka 17 UU No.24 Th 2013 Tentang Perubahan Atas UU No. 23 Tahun 2006 Tentang Administrasi Kependudukan, peristiwa penting adalah kejadian yang dialami oleh seseorang meliputi kelahiran, kematian, lahir mati, perkawinan, perceraian, pengakuan anak, pengesahan anak, pengangkatan anak, perubahan nama dan perubahan status kewarganegaraan. Setelah memperoleh surat penetapan dari pengadilan negeri maka pemohon perubahan atau penambahan nama menyampaikannya ke Dinas Kependudukan dan Catatan Sipil dalam jangka waktu 30 (tiga puluh) hari, dan atas dasar penetapan pengadilan negeri Pejabat Pencatatan Sipil 
membuat catatan pinggir pada register akta Pencatatan Sipil dan kutipan akta Pencatatan Sipil. Hal ini berdasarkan pasal 52 UU No. 23 Th 2006 Tentang Administrasi Kependudukan, yang berbunyi:

(1). Pencatatan perubahan nama dilaksanakan berdasarkan penetapan pengadilan negeri tempat pemohon.

(2). Pencatatan perubahan nama sebagaimana dimaksud pada ayat (1) wajib dilaporkan oleh Penduduk kepada Instansi Pelaksana yang rnenerbitkan akta Pencatatan Sipil paling lambat
30 (tiga puluh) hari sejak diterimanya salinan penetapan pengadilan negeri oleh Penduduk.

(3). Berdasarkan laporan sebagaimana dimaksud pada ayat (2), Pejabat Pencatatan Sipil membuat catatan pinggir pada register akta Pencatatan Sipil dan kutipan akta Pencatatan Sipil.

Berikut contoh subyek hukum yang mengajukan perubahan atau penambahan nama di Dinas Kependudukan dan Catatan Sipil Kabupaten/Kota Serang.

Tabel 2. Permohonan Perubahan Atau Penambahan Nama di Disdukcapil Kab/Kota Serang

\begin{tabular}{clll}
\hline No & \multicolumn{1}{c}{ Pemohon } & \multicolumn{1}{c}{ Nama Awal } & \multicolumn{1}{c}{ Nama Hasil Perubahan } \\
\hline 1 & Hasanah & Hasbullah & Arif Saefulloh \\
2 & Maemunah & Arif Saepulloh & Khaira Adzkiya \\
3 & Maulidinawati & Keisha Fiona Malika & Khenjee Arion Izz Arda Arman \\
4 & Yuli Apriyani & Khenjee Arion Izz A Arman & Salsabila Bilqis Oktaviani Putri \\
5 & Riki Ramadani & Bilqis Oktafiani Putri & Naura Aulia Benlantara \\
6 & Budi Ben & Naura Aulia & Muhaemin \\
7 & Muhaemin & Muhemin & Syakila Afrilia \\
8 & Sohani & Afrila Agustia Ningsih & Catia
\end{tabular}

Sumber: Kantor Dinas Kependudukan dan Catatan Sipil Kabupaten/Kota Serang, 14 Agustus 2020.

\section{Akibat Hukum Perubahan Atau Penambahan Nama Manusia Sebagai Subyek Hukum Terhadap Dokumen Kependudukan dan Dokumen Hukum Lainya}

Perubahan atau penambahan nama subyek hukum dalam dokumen kependudukan adalah perbuatan hukum, karena perbuatan hukum mengandung makna setiap perbuatan atau tindakan subyek hukum yang mempunyai akibat hukum, dan akibat hukum tersebut memang dikehendaki oleh subyek hukum. Akibat hukum menurut A Ridwan Halim adalah segala akibat yang terjadi dari segala perbuatan hukum yang dilakukan oleh subyek hukum terhadap obyek hukum atau pun akibat-akibat lain yang disebabkan karena kejadian-kejadian tertentu yang oleh hukum yang bersangkutan sendiri telah ditentukan atau dianggap sebagai akibat hukum (https://satuhukum.com, 2020). Akibat hukum lahir dari peristiwa hukum atau akibat yang ditimbulkan oleh peristiwa hukum. Dalam kehidupannya manusia mengalami peristiwa hukum seperti : kelahiran, perkawinan, perceraian, kematian dan perubahan atau penambahan nama.

Akibat hukum perubahan atau penambahan nama subyek hukum adalah :

1. Harus mengajukan permohonan perubahan atau penambahan nama melalui surat permohonan ganti nama dan di tanda tangani diatas materai ke pengadilan negeri setempat (sesuai dengan domisili KTP, surat disertai dengan alasan-alasan yang kuat agar mendapat penetapan dari pengadilan negeri), Surat permohonan dilampiri dengan Foto Copy dokumen yang diberi materai dan di stempel kantor pos, didaftar di kepaniteraan pengadilan negeri setempat dengan membayar biaya perkara, menghadiri sidang-sidang dan membawa dua orang saksi. Ha ini berdasarkan kepada ketentuan pasal 52 ayat (1) UU No. 23 Th 2006 Tentang Administrasi Kependudukan, yang berbunyi : "pencatatan perubahan nama dilaksanakan berdasarkan penetapan pengadilan negeri tempat pemohon". Serta ketentuan pasal 53 huruf (a) Perpres No.96 Th 2018 Tentang Persyaratan dan Tata Cara Pendaftaran Penduduk dan Pencatatan Sipil, berdasarkan salinan penetapan pengadilan negeri. Ini adalah akibat hukum, karena jika tidak dilalui/dikuti proses ini maka tidak dapat memperoleh surat penetapan pengadilan negeri.

2. Mengajukan pemohon perubahan atau penambahan nama ke Disdukcapil dalam jangka waktu 30 (tiga puluh) hari, dengan mengisi dan menyerahkan Formulir Pelaporan Perubahan atau Penambahan Nama dengan melampirkan dokumen-dokumen (salinan penetapan perubahan atau penambahan nama dari pengadilan negeri, kutipan akta pencatatan sipil, Kartu Keluarga, KTP-e1, dan Dokumen Perjalanan bagi Orang Asing), kepada Kantor Disdukcapil. Hal ini berdasarkan ketentuan pasal 52 ayat (2) UU No. 23 Th 2006 Tentang Administrasi Kependudukan, yang berbunyi :'Pencatatan perubahan nama sebagaimana dimaksud pada ayat (1) wajib dilaporkan oleh Penduduk kepada Instansi Pelaksana yang rnenerbitkan akta Pencatatan Sipil paling lambat 30 (tiga puluh) hari sejak diterimanya salinan penetapan pengadilan negeri oleh Penduduk". Ini adalah akibat hukum, karena jika tidak dilalui/dikuti proses ini maka tidak dapat merubah atau menambah nama. 
3. Berdasarkan Formulir Pelaporan Perubahan atau Penambahan Nama yang dilengkapi salinan penetapan pengadilan negeri beserta lampiran dokumen lainya Pejabat Pencatatan Sipil membuat catatan pinggir pada register Akta Pencatatan Sipil dan Kutipan Akta Pencatatan Sipil. Pasal 52 ayat (3) UU No. 23 Th 2006 Tentang Administrasi Kependudukan, berbunyi: "Berdasarkan laporan sebagaimana dimaksud pada ayat (2), Pejabat Pencatatan Sipil membuat catatan pinggir pada register Akta dan Kutipan Akta Pencatatan Sipil”. Ini akibat hukum, karena jika tidak ada Pejabat Pencatatan Sipil tidak akan membuat catatan pinggir.

4. Berdasarkan akta kelahiran hasil permohonan perubahan atau penambahan nama tersebut, maka selanjutnya merubah nama subyek hukum pada dokumen-dokumen kependudukan lainnya seperti : KK, KTP, sertipikat tanah, surat-surat sehubungan perbankan, dokumen kontrak, paspor, akta nikah, ijazah dan lain sebagainya. Ini adalah akibat hukum adanya perubahan atau penambahan nama, karena jika tidak diikuti dengan perubahan atau penambahan nama pada dokumen kependudukan lainnya dapat dikhawatirkan dikemudian hari bermasalah dengan hukum.

\section{Kartu Keluarga (KK)}

KK menurut pasal 1 angka 13 UU No.24 Th 2013 Tentang Perubahan Atas UU No. 23 Th 2006 Tentang Administrasi Kependudukan adalah kartu identitas keluarga yang memuat data tentang nama, susunan dan hubungan dalam keluarga, serta identitas anggota keluarga. Menurut Pasal 59 ayat (1) UU No. 23 Th 2006, KK termasuk dokumen kependudukan. Pasal 1 angka 8 UU No.24 Th 2013 Tentang Perubahan Atas UU No. 23 Th 2006, menyatakan bahwa: "Dokumen Kependudukan adalah dokumen resmi yang diterbitkan oleh Instansi Pelaksana yang mempunyai kekuatan hukum sebagai alat bukti autentik yang dihasilkan dari pelayanan Pendaftaran Penduduk dan Pencatatan Sipil”.

Perubahan atau penambahan nama pada akta kelahiran harus pula diikuti perubahan atau penambahan nama pada kartu keluarga (KK). Perubahan atau penambahan nama pada akta kelahiran sebagai peristiwa penting dan juga bagian dari peristiwa kependudukan, yang mana peristiwa kependudukan adalah kejadian yang dialami Penduduk yang harus dilaporkan karena membawa akibat terhadap penerbitan atau perubahan KK, KTP dan/atau surat keterangan kependudukan lainnya meliputi pindah datang, perubahan alamat, serta status tinggal terbatas menjadi tinggal tetap (Pasal 1 angka 11 UU No.24 Tahun 2013).

\section{Kartu Tanda Penduduk Elektronik (KTP el)}

Kartu Tanda Penduduk Elektronik (KTP el) menurut pasal 1 angka 14 UU No. 24 Th 2013 Tentang
Perubahan Atas UU No. 23 Tahun 2006 Tentang Administrasi Kependudukan adalah Kartu Tanda Penduduk yang dilengkapi cip yang merupakan identitas resmi penduduk sebagai bukti diri yang diterbitkan oleh Instansi Pelaksana. Seperti halnya KK, KTP el Menurut Pasal 59 ayat (1) UU No. 23 Th 2006, KTP el termasuk dokumen kependudukan. Menurut Pasal 63 ayat (1) UU No.24 Tahun 2013, bagi subyek hukum yang sudah memiliki KTP el, yaitu telah berumur 17 (tujuh belas) tahun atau telah kawin atau pernah kawin wajib memiliki KTP el, perubahan atau penambahan nama pada akta kelahiran disamping dikuti perubahan atau penambahan nama pada KK, juga pada KTP el. Pasal 64 ayat (8) UU No.24 Th 2013, menyatakan: "Dalam hal terjadi perubahan elemen data, rusak, atau hilang, Penduduk pemilik KTP-el wajib melaporkan kepada Instansi Pelaksana untuk dilakukan perubahan atau penggantian".

\section{Akta Perkawinan/Akta Nikah/Buku Nikah}

Akta Perkawinan/Akta Nikah/Buku Nikah adalah tergolong sebagai alat bukti autentik adanya peristiwa penting, hasil pencatatan sipil, yang mana peristiwa penting adalah kejadian yang dialami oleh seseorang meliputi kelahiran, kematian, lahir mati, perkawinan, perceraian, pengakuan anak, pengesahan anak, pengangkatan anak, perubahan nama dan perubahan status kewarganegaraan (Pasal 1 angka 17 UU No.24 Tahun 2013). Bukti autentik yang memuat peristiwa hukum perkawinan, sehingga perkawinan mempunyai kekuatan hukum yang pasti (Nunung Rodliyah, 2013). Akibat hukum adanya perubahan atau penambahan nama membawa akibat harus pula melakukan perubahan nama pada Akta Perkawinan/Akta Nikah/Buku Nikah tersebut bagi yang sudah menikah. Pokoknya semua dokumen yang terkait, semua dokumen yang mencantumkan nama lama juga harus diubah, KK, KTP, akte kelahiran, akta/buku nikah (jika sudah menikah), akta kelahiran anak (jika sudah punya anak), paspor (jika punya), dan ijazah (jika diperlukan) (www.kompasiana.com, 2019).

Adapun dasar hukum tata cara perubahan atau penambahan nama pada Akta Nikah/Buku Nikah bagi penduduk yang beragama Islam adalah berdasarkan Peraturan Menteri Agama (PMA) No.20 Th 2019 tentang Pencatatan Pernikahan. Pasal 38 ayat (1,2 dan 3) PMA tersebut berbunyi:

(1) Perubahan nama suami atau istri pada Akta Nikah dilakukan oleh KUA Kecamatan berdasarkan akta kelahiran yang baru.

(2) Pencatatan perubahan data perseorangan berupa tempat, tanggal, bulan, tahun lahir, nomor induk kependudukan, kewarganegaraan, pekerjaan, dan alamat dilakukan oleh KUA Kecamatan berdasarkan surat keterangan dari dinas kependudukan dan pencatatan sipil. 
(3) Tata cara penulisan perubahan sebagaimana dimaksud pada ayat (1) dan ayat (2) ditetapkan dengan Keputusan Direktur Jenderal.

Kemudian menurut Keputusan Dirjen Bimas Islam No.473 Th 2020 tentang Petunjuk Teknis Pencatatan Pernikahan, yang tercantum dalam Bab V tentang Tata cara Penulisan Perubahan Nama atau Data Perseorangan, yang berbunyi:

Perubahan nama atau data perseorangan pada Akta Nikah dan atau Buku Nikah dapat dilakukan dengan ketentuan sebagai berikut:

a. Tata cara penulisan perubahan nama atau data perseorangan pada Akta Nikah atau Buku Nikah bagi yang belum menggunakan Aplikasi SIMKAH dilakukan pada kolom catatan pada Akta Nikah dengan menulis kalimat "nama suami/istri telah diubah menjadi............pada tanggal......."sedangkan pada Buku Nikah dilakukan pada kolom catatan dengan menulis kalimat nama suami/istri telah diubah menjadi. .pada tanggal........";

b. Tata cara penulisan perubahan nama atau data perseorangan pada Akta Nikah atau Buku Nikah bagi yang sudah menggunakan Aplikasi SIMKAH dengan melakukan perbaikan pada menu edit Akta Nikah atau Buku Nikah dengan mencetak ulang kolom catatan pada Akta Nikah atau Buku Nikah dengan kaliimat sebagaimana pada poit A;

c. Dalam hal penulisan perubahan nama atau data perseorangan pada Akta Nikah atau Buku Nikah mengakibatkan kerusakan dapat dilakukan penggantian Akta Nikah atau Buku Nikah.

Untuk mengajukan permohonan perubahan atau penambahan nama pada Akta Nikah atau Buku Nikah ke KUA, pemohon harus mengajukan permohonan disertai alasan perubahan dan membawa Buku Nikah Asli dilengkapi dokumen pendukung bukti penyesuaian perubahan seperti : Surat Pengantar dari Kelurahan/Desa, KTP el, KK, Ijazah, dan akta kelahiran. Atas dasar permohonan perubahan dilengkapi dokumen pendukungnya pihak KUA akan memprosesnya sesuai PMA No.20 Th 2019 jo Keputusan Dirjen Bimas Islam No 473 Th 2020. Berikut ini contoh perubahan atau penambahan nama pada akta dan buku nikah.

Tabel 3. Permohonan Perubahan Atau Penambahan Nama Pada Akta Nikah/Buku Nikah

\begin{tabular}{clll}
\hline No & \multicolumn{1}{c}{ Pemohon } & \multicolumn{1}{c}{ Nama Awal } & Nama Hasil Perubahan Junaidi \\
\hline 1 & Jujun Junaidi & Jujun & Mad Idrus \\
2 & Mad Idrus & M. Idrus & Azizi Yahya \\
3 & Azizi Yahya & Azizi & Nurul Huda Solihin \\
4 & Nurul Huda Solihin & Nurul Huda & H. Asep Saefulloh \\
5 & H. Asep Saefulloh & Asep Saefullah & Husnawati \\
6 & Husnawati & Husnah & Nurul Hofiyah \\
7 & Nurul Hofiyah & Nurul Hofiah & Saeful Bahri \\
8 & Saeful Bahri & Syaiful Bahri & Juwariyah \\
9 & Juwariyah & Juhairah & Suliah \\
\hline 10 & Suliah & Suliyah & \\
\hline
\end{tabular}

Sumber : Kantor KUA kecamatan Serang dan Cipocok Kota Serang, 01 dan 10 September 2020.

\section{Paspor}

Paspor sebagai dokumen perjalanan adalah dokumen resmi yang memuat identitas seseorang atau pemegangnya. Paspor diterbitkan oleh lembaga atau pejabat yang berwenang di suatu negara dan berlaku untuk digunakan sebagai identitas ketika seseorang akan melakukan perjalanan antar negara. Pasal 1 angka 16 UU No.6 Th 2011 tentang Keimigrasian, menyatakan bahwa: "Paspor Republik Indonesia yang selanjutnya disebut Paspor adalah dokumen yang dikeluarkan oleh Pemerintah Republik Indonesia kepada warga negara Indonesia untuk melakukan perjalanan antarnegara yang berlaku selama jangka waktu tertentu". Paspor berisi biodata pemegangnya yang meliputi antara lain: nama, foto pemegang, tanda tangan, tempat dan tanggal kelahiran, informasi kebangsaan dan kadang-kadang juga beberapa informasi lain mengenai identifikasi individual. Adakalanya pula sebuah paspor mencantumkan daftar negara yang tidak boleh dimasuki oleh si pemegang paspor itu (Wikipedia bahasa Indonesia, ensiklopedia bebas, 2019).

Paspor sebagai dokumen resmi perjalanan berisi biodata, tentu saja harus ada kesesuaian data dengan dokumen kependudukan lainya yang menjadi syarat bagi pembuatan paspor tersebut. Oleh karena itu jika terjadi perubahan atau penambahan nama pada dokumen kependudukan dan catatan sipil, seperti : akta kelahiran, KK dan KTP, akta/buku nikah maka harus pula merubah data pada paspor dalam rangka mengantisipasi permasalahan hukum yang mungkin terjadi karena adanya perbedaan data pada dokumen-dokumen tersebut.

Prosedur perubahan data paspor biasa menurut Pasal 24 Permenkumham No.8 Th 2014 tentang Paspor Biasa dan Surat Perjalanan Laksana Paspor, yang meliputi perubahan nama atau perubahan alamat, dapat mengajukan permohonan perubahan data Paspor biasa kepada Kepala Kantor Imigrasi atau Pejabat Imigrasi : (1) pengajuan permohonan; (2) persetujuan Kepala 
Dede Agus dan Lia Riesta Dewi, Pelaksanaan Jaminan Hak Keperdataan Subyek Hukum Manusia Atas Perubahan Atau Penambahan Nama Dalam Hukum Positif Indonesia Di Serang Banten

Kantor Imigrasi atau Pejabat Imigrasi; dan (3) pencetakan perubahan data pada halaman pengesahan. Dokumen untuk pengurusan perubahan data di paspor adalah : (1) KTP asli dan fotokopi; (2) KK asli dan fotokopi; (3) Akte Kelahiran/Ijazah asli dan fotokopi; (4) Paspor asli dan fotokopi; dan (5) Formulir Imigrasi (biasanya disediakan di koperasi kantor imigrasi) (Indonesia.go.id, portal informasi Indonesia, 2019). Ada dua cara untuk mengganti data identitas yang keliru di paspor. Pertama, melalui endorsement atau penambahan nama pada halaman 4 paspor, namun kelemahan sistem endorsement, ada beberapa negara yang tak menerima adanya catatan khusus tersebut. Adapun cara kedua adalah dengan mengganti dan mencetak ulang paspor. Cara kedua ini lebih rumit dan membutuhkan waktu yang lebih lama dibandingkan cara pertama (Indonesia.go.id, portal informasi Indonesia, 2019). Berikut ini contoh perubahan atau penambahan nama pada paspor.

Tabel 4. Permohonan Perubahan Atau Penambahan Nama Pada Paspor

\begin{tabular}{|c|c|c|c|}
\hline No & Pemohon & Nama Awal & Nama Hasil Perubahan \\
\hline 1 & Agus Tugiman & Tugiman & Agus Tugiman \\
\hline 2 & Anie Saputri & Ani Sulastri & Anie Saputri \\
\hline 3 & Sanah & Ani Maemunah BT Samidi Ali & Sanah \\
\hline 4 & Muhamad Rofik Padlilah & Ovik & Muhamad Rofik Padlilah \\
\hline
\end{tabular}

Sumber : Kantor Imigrasi Serang, 14 September 2020.

\section{Ijazah, Sertifikat, Dokumen Kontrak, Perbankan, BPKB, STNK dan SIM}

Perubahan atau penambahan nama pada dokumen kependudukan dan catatan sipil, seperti : akta kelahiran, akta/buku nikah, KK, KTP dapat membawa dampak untuk merubah dokumen-dokumen seperti: Ijazah, Sertifikat, Dokumen Kontrak, Perbankan, BPKB, STNK dan SIM. Karena kalau tidak diikuti/ditindaklanjuti dengan perubahan identitas nama pada berbagai dokumen tersebut mungkin saja menimbulkan permasalahan hukum ketika digunakan. Ijazah dibuat berlandaskan pada dokumen kependudukan dan catatan sipil atau ijazah dibawahnya/dibuat sebelumnya untuk identitasnya, jika terjadi perbedaan dapat saja terjadi permasalahan ketika digunakan. Untuk solusinya pemilik ijazah tentu harus mengurusnya ke instansi/lembaga yang menerbitkannya, untuk membuat surat keterangan dari instansi/lembaga yang berwenang menerbitkannya. Hal ini karena perubahan atau penambahan nama pada ijazah hanya dapat dilakukan jika masih dalam masa tahun kelulusan (masih dalam masa tenggang 6 bulan), jika lewat masa tenggang tersebut hanya dapat dilakukan dengan membuat surat keterangan perubahan atau penambahan nama (wawancara dengan Pihak Dinas Pendidikan dan Kebudayaan Kabupaten/Kota Serang, tgl. 11 dan 18 September 2020). Perihal perubahan atau penambahan nama ijazah pengaturannya terdapat dalam Permendikbud No. 29 Th 2014 Tentang Pengesahan Fotokopi Ijazah/Surat Tanda Tamat Belajar, Surat Keterangan Pengganti Ijazah/Surat Tanda Tamat Belajar dan Penerbitan Surat Keterangan Pengganti Ijazah/Surat Tanda Tamat Belajar Jenjang Pendidikan Dasar Dan Menengah, pada lampiran Format IC: Surat Keterangan Kesalahan Penulisan Ijazah/STTB. Sertifikat, Dokumen Kontrak, Perbankan, BPKB, STNK dan SIM biasanya dibuat berdasarkan/berlandaskan dokumen kependudukan berupa : KK dan KTP, dan jika terjadi perbedaan dapat saja terjadi permasalahan ketika digunakan. Untuk solusinya pemilik dokumen tersebut tentu harus mengurusnya ke instansi/lembaga yang menerbitkannya, apakah dibuat/dilampirkan/dicetak/dan lain-lain cara tergantung dari instansi/lembaga yang berwenang menerbitkan/membuatnya.

5. Akibat Hukum dikenakan Sanksi/Sanksi Yang Dapat Diterima

Akibat hukum perubahan atau penambahan nama tanpa surat penetapan pengadilan negeri setempat tidak dapat dikabulkan oleh Dinas Kependudukan dan Catatan Sipil, dan ini termasuk sanksi tidak dapat diterima permohonan. Sanksi lainnya adalah tidak dilaporkan perubahan atau penambahan nama yang telah mendapat surat penetapan pengadilan negeri ke Dinas Kependudukan dan Catatan Sipil dalam jangka waktu 30 (tiga puluh) hari dikenakan sanksi administratif berupa denda. Hal ini mengandung makna bahwa perubahan atau penambahan nama hasil penetapan pengadilan negeri harus ditindaklanjuti dengan perubahan atau penambahan nama pada dokumen kependudukan dan catatan sipil di Dinas Kependudukan dan Catatan Sipil. Dalam arti harus merubah atau menambah nama pada akta kelahiran, akta perkawinan/buku nikah (bagi yang sudah menikah), Kartu Keluarga (KK), KTP el dan dokumen lainnya. Ketentuan sanksi berdasarkan pasal 90 ayat (1) huruf (j), ayat (2) dan (3) UU No. 23 Th 2006 Tentang Administrasi Kependudukan, yang berbunyi:

(1). Setiap Penduduk dikenai sanksi administratif berupa denda apabila melampaui batas waktu pelaporan Peristiwa Penting dalam hal: (j) perubahan nama sebagaimana dimaksud dalam Pasal 52 ayat (2); 
(2). Denda administratif sebagaimana dimaksud pada ayat (1) paling banyak Rp.1.000.000,00 (satu juta rupiah).

(3). Ketentuan lebih lanjut mengenai penetapan denda administratif sebagaimana dimaksud pada ayat (2) diatur dalam Peraturan Presiden.

Selanjutnya pasal 73 Perpres No. 96 Th 2018 Tentang Persyaratan dan Tata Cara Pendaftaran Penduduk dan Pencatatan Sipil, berbunyi:

(1). Pelaporan Peristiwa Kependudukan dan Peristiwa Penting yang melampaui batas waktu dikenai denda administratif sesuai dengan ketentuan peraturan perundang-undangan.

(2). Pengenaan denda administratif sebagaimana dimaksud pada ayat (1) dilaksanakan setelah diberikan teguran lisan dan teguran tertulis dan mempertimbangkan kemampuan Penduduk yang bersangkutan.

Sanksi juga dapat diterima oleh subyek hukum yang melakukan perubahan atau penamahan nama jika perubahan pada dokumen kependudukan dan catatan sipil tidak diikuti/disesuaikan dengan perubahan nama pada dokumen lainya seperti : Paspor, Ijazah, Sertifikat, Dokumen Kontrak, Perbankan, BPKB, STNK dan SIM, berupa penolakan pengguanaan dokumen-dokumen tersebut atau tidak diterimanya suatu perbuatan hukum dengan alasan tidak sama identitas nama subyek hukumnya.

\section{SIMPULAN}

Berdasarkan hasil penelitian dan pembahasan di atas maka dapat disimpulkan :

1. Perubahan atau penambahan nama subyek hukum manusia (orang) dalam dokumen kependudukan dan catatan sipil telah dijamin secara implisit oleh UU No. 39 Th 1999 tentang Hak Asasi Manusia, UU No. 23 Th 2002 tentang Perlindungan Anak dan UU No.1 Th 1974 Tentang Perkawinan, dan secara eksplisit oleh UU Administrasi Kependudukan baik UU No. 23 Th 2006 Tentang Administrasi Kependudukan dan UU No. 24 Th 2013 tentang perubahannya, serta peraturan pelaksanaannya. Begitu pula pelaksanaan hak keperdataan atas perubahan atau penambahan nama dalam dokumen kependudukan dan catatan sipil, serta dokumen lainya dalam praktek telah berjalan. Hal ini ditandai dengan adanya subyek hukum manusia mengurus dan mengajukan permohonan perubahan atau penambahan nama dalam berbagai dokumen, mulai dari pengadilan negeri sampai kepada lembaga/instansi yang ada kaitanya dengan dokumen kependudukan dan catatan sipil maupun dokumen lainya.
2. Perubahan atau penambahan nama manusia sebagai subyek hukum dalam dokumen kependudukan dan catatan sipil menimbulkan akibat hukum yang luas, yaitu : harus mengajukan permohonan agar mendapat surat penetapan perubahan atau penambahan nama dari pengadilan negeri. Mengajukan pemohon perubahan atau penambahan nama ke Disdukcapil dalam jangka waktu 30 (tiga puluh) hari. Pejabat Pencatatan Sipil membuat catatan pinggir pada register Akta Pencatatan Sipil dan Kutipan Akta Pencatatan Sipil. Merubah identitas nama subyek hukum pada dokumen kependudukan lainnya seperti : KK, KTP, paspor, akta nikah/buku nikah, serta dokumen lainnya seperti: ijazah, sertipikat tanah, surat-surat perbankan, dokumen kontrak, dan lain sebagainya, karena jika tidak disertai/diikuti dengan perubahan nama pada dokumen tersebut dapat dikhawatirkan dikemudian hari bermasalah dengan hukum. Akibat hukum dikenakan sanksi/sanksi yang dapat diterima: perubahan atau penambahan nama tanpa surat penetapan pengadilan negeri tidak dapat dikabulkan oleh Disdukcapil. Perubahan atau penamahan nama tidak dilaporkan ke Disdukcapil dalam jangka waktu 30 (tiga puluh) hari dikenakan sanksi administratif berupa denda. Sanksi juga dapat diterima oleh subyek hukum jika perubahan pada dokumen kependudukan dan catatan sipil tidak diikuti/disesuaikan dengan perubahan nama pada dokumen lainya, berupa penolakan pengguanaan dokumen-dokumen tersebut atau tidak diterimanya suatu perbuatan hukum dengan alasan tidak sama identitas nama subyek hukumnya.

\section{DAFTAR PUSTAKA}

Adelin, Fadila, Kalau mau ganti nama jangan lupa bubur merah putihnya, https://www.brilio.net/reporter, 09/10/2015, diakses 05/7/2020 pukul 08.15 WIB.

Harahap, M Yahya, 2016, Hukum Acara Perdata: Gugatan, Persidangan, Penyitaan, Pembuktian dan Putusan Pengadilan, Sinar Grafika, Jakarta.

Hutomo, Dimas, Perlukah Alasan Perubahan Nama Disebutkan Pada Permohonan?, https://www.hukumonline.com/klinik, Kamis, 11 Juli 2019, diakses tgl 4/7/2020, pukul 11.40 WIB.

https://SatuHukum.com, Apa itu akibat hukum? Diunduh 29/7/2020, pukul 05.46 WIB.

http://dariuslekalawo.blogspot.com/search/label/ilmu hukum, Apa Perbedaan Putusan dan Penetapan? Senin, 04 Mei 2015, diakses tgl 27/7/2020, pukul 13.22 WIB.

Indonesia.go.id, portal informasi Indonesia, Mengubah Data Paspor: Cara Mengubah Data Diri Di Paspor, 19 Mei 2019, diakses 27 Oktober 2020 pukul 07.30 WIB. 
Dede Agus dan Lia Riesta Dewi, Pelaksanaan Jaminan Hak Keperdataan Subyek Hukum Manusia Atas Perubahan Atau Penambahan Nama Dalam Hukum Positif Indonesia Di Serang Banten

Mahfan, 2005, Kamus Bahasa dan Sastra Indonesia, Sandro Jaya, Jakarta.

Mahmud Marzuki, Peter, 2007, Penelitian Hukum, Kencana Prenada Media Group, Jakarta.

Mertokusumo, Sudikno, 2003, Mengenal Hukum: Suatu Pengantar, Liberty, Yogyakarta.

Rodliyah, Nunung, 2013, "Pencatatan Pernikahan dan Akta Nikah Sebagai Legalitas Pernikahan Menurut Kompilasi Hukum Islam", Jurnal Pranata Hukum: Bandar Lampung, Vol. 8 No.1, Januari 2013.

Sistem Informasi Penelusuran Perkara (SIPP) PN Serang, Daftar Perkara Permohonan, Tahun 2015, sipp.pn-serang.go.id, diunduh tgl 24/7/2020, pukul 10.20 WIB.

Tendiyanto, Teten, Nama dan Perubahan Nama dalam KUH Perdata (Kitab Undang-undang Hukum Perdata), www.tenzdiyanto.blogspot.com, Senin, 24 Maret 2014.

Usman, Rahmadi, 2006, Aspek-aspek Hukum Perorangan dan Kekeluargaan di Indonesia, Sinar Grafika, Jakarta.

Wikipedia bahasa Indonesia, ensiklopedia bebas: Paspor, https://id.wikipedia.org/wiki/paspor, 28/2/2019, diakses 02/8/2020, 12.31 WIB.

www.kompasiana.com, Gampang-gampang Susah Mengurus Ganti Nama di Pengadilan Negeri, 29 Juli 2019 dan 30 Juli 2020, diakses tgl. 02/8/2020, pukul 11.50 WIB.

Zulkarnain, Akhmad, Kategori Maskulin dan Feminim dalam Nama Orang Eropa, http://akhmadzulkarnain.web.ugm.ac.id/author/ak hmad-zulkarnain, 23/01/2016.

Zainuddin, Muslim dan Mansari, 2018, "Strategi Perluasan Cakupan Akta Kelahiran Sebagai Wujud Pemenuhan Hak Anak Di Banda Aceh dan Aceh Besar", Gender Equality: Internasional Journal of Child and Gender Studies, Vol. 4, No. 1, Maret 2018.

BW (Kitab Undang-undang Hukum Perdata)

Undang-Undang No.1 Tahun 1974 Tentang Ketentuanketentuan Pokok Perkawinan.

Undang-Undang No. 23 Tahun 2006 Tentang Administrasi Kependudukan

Undang-Undang Nomor 24 Tahun 2013 Tentang Perubahan Atas Undang-Undang No. 23 Tahun 2006 Tentang Administrasi Kependudukan.

Undang-Undang Nomor 6 tahun 2011 Tentang Keimigrasian

Peraturan Presiden Nomor 96 Tahun 2018 Tentang Persyaratan dan Tata Cara Pendaftaran Penduduk dan Pencatatan Sipil.

Peraturan Menteri Agama Nomor 20 Tahun 2019 Tentang Pencatatan Pernikahan.
Permenkumham Nomor 8 Tahun 2014 Tentang Paspor Biasa dan Surat Perjalanan Laksana Paspor.

Keputusan Direktur Jenderal Bimbingan Masyarakat Islam No 473 Tahun 2020 Tentang Petunjuk Teknis Pencatatan Pernikahan. 